\title{
5: $121441853-121429918$
}

National Cancer Institute

\section{Source}

National Cancer Institute. 5:121441853-121429918. NCI Thesaurus. Code C45113.

Physical location of LOX_Gene 